\title{
Nitrogen use efficiency and rice yield as influenced by the application of prilled urea and urea super granule with or without organic manure
}

\author{
M. R. Husan*, M. R. Islam, K. Faried and M. H. Mian \\ Department of Soil Science, Bangladesh Agricultural University, Mymensingh-2202, Bangladesh, *E-mail: husanrubel \\ @ gmail.com.
}

\begin{abstract}
An experiment was conducted to examine the effect of prilled urea (PU), and urea super granule (USG) alone or in combination with poultry manure or cowdung on $\mathrm{NH}_{4}-\mathrm{N}$ content of rice field with nitrogen use efficiency (NUE) and the yield of rice (cv. BRRI dhan50). The experiment was carried out at the Soil Science Field Laboratory of Bangladesh Agricultural University, Mymensingh during Boro season of 2012 and laid out in a randomized complete block design with three replications. There were six treatments viz. $T_{1}$ (Control), $T_{2}$ (78 kg N ha ${ }^{-1}$ from USG), $T_{3}$ (136 $\mathrm{kg} \mathrm{N} \mathrm{ha}^{-1}$ from PU), $T_{4}\left(58 \mathrm{~kg} \mathrm{~N} \mathrm{ha}^{-1}\right.$ from USG), $T_{5}\left(58 \mathrm{~kg} \mathrm{~N} \mathrm{ha}^{-1}\right.$ from USG $+3 \mathrm{tha}^{-1}$ poultry manure) and $\mathrm{T}_{6}$ (58 $\mathrm{kg} \mathrm{N}^{-1}$ $\mathrm{ha}^{-1}$ from USG $+5 \mathrm{t} \mathrm{ha}^{-1}$ cowdung). All plots received recommended doses of $\mathrm{P}, \mathrm{K}, \mathrm{S}$ and $\mathrm{Zn}$ fertilizers. The $\mathrm{NH}_{4}-\mathrm{N}$ in rice field water increased rapidly when $\mathrm{N}$ was applied as PU. In contrast, NH4-N release was very slow when applied as USG over the crop growth period. Application of PU, USG alone or in combination with poultry manure or cowdung significantly influenced grain and straw yield, all the yield components except 1000-grain weight of BRRI dhan50. Urea super granule with poultry manure (treatment $\mathrm{T}_{5}$ ) produced the highest grain and straw yield and the lowest values were recorded from control. Nitrogen content and uptake, apparent $\mathrm{N}$ recovery and NUE were also influenced significantly by the application of PU, and USG alone or in combination with organic manure. Among the treatments, $\mathrm{T}_{5}$ demonstrated the highest $\mathrm{N}$ recovery and NUE. The overall results suggest that application of USG in combination with poultry manure could be considered more effective for increasing the yield and NUE of BRRI dhan50.
\end{abstract}

Keywords: Prilled urea, USG, Organic manure, NUE, BRRI dhan50

\section{Introduction}

Nitrogen $(\mathrm{N})$ is the most limiting factor in crop production. Hence, application of $\mathrm{N}$ fertilizer results in higher biomass yields and protein content in plant tissue (Blumenthal et al., 2008).In most cases, surface broadcasting of $\mathrm{PU}$ is practiced by farmers to meet up the $\mathrm{N}$ demand for rice crop. Broadcasting of urea to agricultural soils can result in considerable losses by $\mathrm{NH}_{3}$ volatilization (Rochette et al., 2009). Ammonia $\left(\mathrm{NH}_{3}\right)$ volatilization is an important pathway for fertilizer $\mathrm{N}$ loss from soil and is also a major source of air and environmental pollution (Wang et al., 2004). Bhuiyan et al. (1988) reported that deep point placement of USG produced significantly higher grain yield of rice than split application of PU. Further, increases in grain yield, better $\mathrm{N}$ use efficiency (kg grain per $\mathrm{kg} \mathrm{N}$ ) and higher apparent $\mathrm{N}$ recovery occurred when the whole was closed after USG application. Similarly, Mohanty et al. (1999) reported that USG deep placement resulted in additional grain yield of 1080,510 and $350 \mathrm{~kg} / \mathrm{ha}$ over prilled urea in alternate wetting and drying, shallow low land and intermediate low land, respectively. Broadcast application of $\mathrm{N}$ as urea resulted in an average 10 times higher amounts of ammonium $\mathrm{N}$ in flood water compared to deep placement of urea briquette and NPK briquette (Kapoor et al. (2008).

There is increased emphasis on the impact on environmental quality due to continuous use of chemical fertilizers. The integrated nutrient management system is an alternative and is characterized by reduced input of chemical fertilizers and combined use of chemical fertilizers with organic materials such as animal manures, crop residues, green manure and composts. Based on the evaluation of soil quality indicators, Dutta et al. (2003) reported that the use of organic fertilizers together with chemical fertilizers, compared to the addition of organic fertilizers alone, had a higher positive effect on microbial biomass and soil health. Application of organic manure in combination with chemical fertilizer has been reported to increase absorption of $\mathrm{N}, \mathrm{P}$ and $\mathrm{K}$ in sugarcane leaf tissue in the plant and ratoon crop, compared to chemical fertilizer alone (Bokhtiar \& Sakurai, 2005). In the recent years poultry farms of different sizes have been established all over the country. As poultry excreta are rich in nutrients, these can be a good source of manure of field crops. Poultry manure is widely used as an alternative source of N, P, and K for crops and forages and is often applied at excessive rates of both $\mathrm{N}$ and $\mathrm{P}$ (Mitchell \& Tu, 2006). 
Therefore, use of poultry manure (PM) and cowdung (CD) in combination with USG may optimize the need for $\mathrm{N}$ requirement of rice. Therefore, the present study was undertaken to examine the effect of $\mathrm{PU}$ and USG alone or in combination with poultry manure or cowdung on water $\mathrm{NH}_{4}-\mathrm{N}$ content, apparent $\mathrm{N}$ recovery, NUE and the yield of BRRI dhan50.

\section{Materials and Methods}

\section{Experimental site and period}

The field experiment was carried out at the Soil Science Field Laboratory of Bangladesh Agricultural University, Mymensingh from January to May, 2012.

\section{Soil}

Experimental fields belong to the Non-calcareous Dark Grey Floodplain Soils under the Old Brahmaputra Floodplain agro-ecological region (FAO-UNDP, 1988). The soil was silt loam in texture having $\mathrm{pH} 6.09$, organic matter content $2.02 \%$, total $\mathrm{N} 0.117 \%$, available P $3.19 \mathrm{ppm}$, exchangeable $\mathrm{K} 0.092 \mathrm{me} \%$,

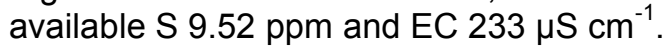

\section{Treatments}

The experiment was laid out in a Randomized Complete Block Design (RCBD) with three replications. There were six treatments viz. $T_{1}$ (Control), $T_{2}$ (78 kg N ha-1 from USG), $T_{3}$ (136 kg N ha ${ }^{-1}$ from PU), $T_{4}$ (58 kg N ha-1 from USG), $T_{5}$ (58 kg N ha ${ }^{-1}$ from USG $+3 \mathrm{t} \mathrm{ha}^{-1}$ poultry manure) and $T_{6}\left(58 \mathrm{~kg} \mathrm{~N} \mathrm{ha}^{-1}\right.$ from USG $+5 \mathrm{t} \mathrm{ha}^{-1}$ cowdung). The nutrient content of cowdung and poultry manure has been depicted below:

Table 1. Nutrient content of cowdung and poultry manure

\begin{tabular}{|c|c|c|c|c|}
\hline \multirow{2}{*}{ Manure } & \multicolumn{4}{|c|}{ Nutrient content (\%) } \\
\cline { 2 - 5 } & $\mathrm{N}$ & $\mathrm{P}$ & $\mathrm{K}$ & $\mathrm{S}$ \\
\hline Poultry manure & 1.18 & 1.13 & 0.81 & 0.35 \\
\hline Cowdung & 0.57 & 0.47 & 0.69 & 0.17 \\
\hline
\end{tabular}

\section{Cultural Operations}

Thirty-five-day old rice seedlings were transplanted at a spacing of $20 \mathrm{~cm} \times 10 \mathrm{~cm}$. Intercultural operations such as irrigation and drainage, weeding and pest control were done when required. The first dose of PU and USG was applied 8 days after transplanting (DAT); the second dose of PU was added as top dressing 38 DAT (active tillering stage); the third dose of PU was added as top dressing 68 DAT (panicle initiation stage).

\section{Data Collection}

The plant height was measured from the ground level to the top of the panicle. Total numbers of effective tillers hill ${ }^{-1}$ and filled grains panicle ${ }^{-1}$ were also measured. Panicle length was measured from basal node of the rachis to apex of each panicle. The 1000-grain weight was recorded by an electrical balance after sun drying. Grain and straw yields were recorded from $1 \mathrm{~m}^{2}$ area of each plot and expressed in $\mathrm{kg} / \mathrm{ha}$.

\section{Analyses of Soil Samples}

The initial soil samples were analyzed for soil texture, $\mathrm{pH}$, and organic matter, total $\mathrm{N}$, available $\mathrm{P}$, exchangeable K and EC. Particle size analysis of soil was done by hydrometer method ((Black, 1965) and the textural class was determined from Marshall's Triangular Coordinate. Soil pH was measured with the help of a glass electrode $\mathrm{pH}$ meter (Michael, 1965). Organic matter was determined by wet oxidation method ((Walkley and Black, 1934). Total N was determined by Semi-micro Kjeldahl method (Bremner and Mulvaney, 1982) and available $\mathrm{P}$ was determined colorimetrically by stannous chloride $\left(\mathrm{SnCl}_{2}\right)$ method (Olsen et al., 1954). Exchangeable $\mathrm{K}$ and available $\mathrm{S}$ were determined by flame photometer (Knudsen et al., 1982) and a spectrophotometer method (Williams and Steinbergs, 1959), respectively. The EC of soil was determined by conductivity meter. 


\section{Water sampling}

The surface water in the rice field was collected twice, at first top dressing of PU and deep placement of USG and at second top dressing of PU. Both the time water sampling was done before irrigation and two hours after irrigation followed by next seven days sampling maintaining a specific time of the day to analyze flood water $\mathrm{NH}_{4}-\mathrm{N}$.

\section{Determination of $\mathrm{NH}_{4}-\mathrm{N}$}

Ammonium nitrogen of water samples was determined by titrimetric method as outlined by APHA (1998).

\section{Measurement of nitrogen}

Nitrogen contents in the plant samples were determined by Kjeldahl method. Nitrogen uptake was calculated multiplying the $\mathrm{N}$ content (\%) by the corresponding yield divided by 100 .

Apparent N Recovery (ANR) was measured by the following formula:

$\operatorname{ANR}\left(\mathrm{kgha}^{-1}\right)=\frac{\mathrm{NU}_{\mathrm{F}}-\mathrm{NU} \mathrm{C}}{\mathrm{FN}}$

Where, $\mathrm{NU}_{\mathrm{F}}=$ Total $\mathrm{N}$ uptake in fertilized plot, $\mathrm{NU}_{\mathrm{C}}=$ Total $\mathrm{N}$ uptake in control plot and $\mathrm{FN}=$ Fertilizer $\mathrm{N}$ applied $\left(\mathrm{kg} \mathrm{ha}^{-1}\right)$.

Nitrogen Use Efficiency (NUE) was measured by the following formula:

NUE $=\frac{Y_{F}-Y_{C}}{F N}$

Where, $Y_{F}=$ Yield of fertilized plot, $Y_{C}=$ Yield of control plot and $F N=$ Fertilizer $N$ applied $\left(\mathrm{kg} \mathrm{ha}^{-1}\right)$.

\section{Statistical Analysis}

The analysis of variance of different parameters of the treatments was made and then mean differences were judged by Duncan's New Multiple Range Test (DMRT) (Gomez and Gomez, 1984).

\section{Results and Discussion}

\section{Irrigation water $\mathrm{NH}_{4}-\mathrm{N}$}

Fig. 1 shows the effect USG and $\mathrm{PU}$ on $\mathrm{NH}_{4}-\mathrm{N}$ concentration of water in BRRI dhan50 field. The amount of $\mathrm{NH}_{4}-\mathrm{N}$ in the BRRI dhan50 field water was determined consecutively for 7 days after the application of $\mathrm{PU}$ and USG to monitor the release and availability of $\mathrm{NH}_{4}-\mathrm{N}$ from nitrogenous fertilizers. The measurement was done three times. First measurement was done after application of first split of PU as well as deep placement of USG. Second one was done after application of second split of PU and the third one was done after the application of third split of PU. In first sampling, the amount of available $\mathrm{NH}_{4}$ $\mathrm{N}$ in rice field water started to increase after 2 hours of application, continued up to 2 days and then decreased gradually (Fig. 1). Similar results were obtained for the $2^{\text {nd }}$ and $3^{\text {rd }}$ sampling (data not shown). In comparison with PU, the USG application generated available $\mathrm{NH}_{4}{ }^{+}-\mathrm{N}$ slowly rather spontaneously over the time indicating a beneficial role of USG. 


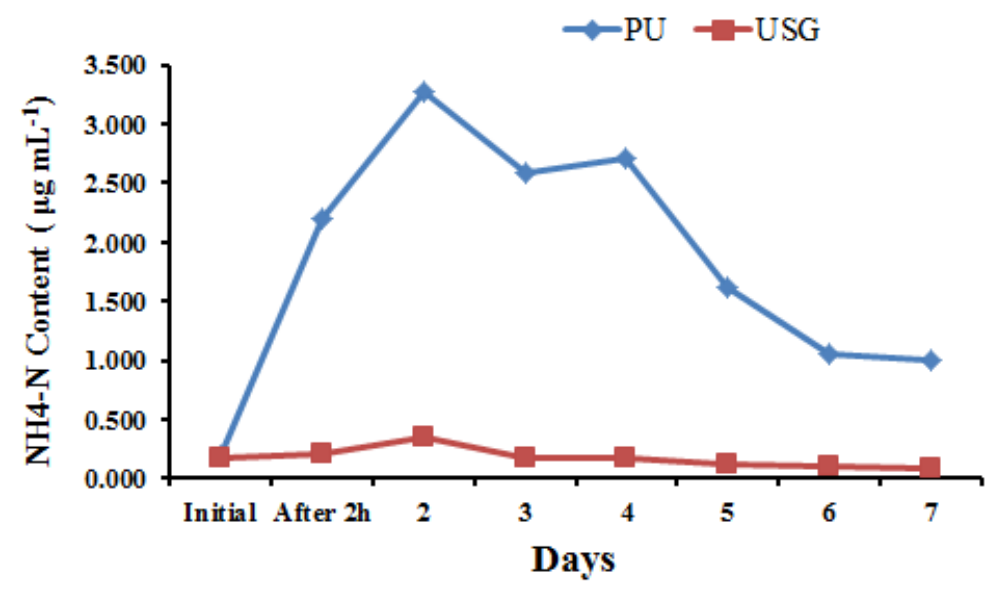

Fig. 1. Effect of $P U$ and USG on the $\mathrm{NH}_{4}-\mathrm{N}$ content of irrigation water

Yield contributing characters of BRRI dhan50: The effect of nitrogen supplied from PU, USG and manures on the yield components of BRRI dhan50 has been shown in Table 2. Plant height was increased due to application of USG alone or in combination with poultry manure. The tallest plant of 88.9 $\mathrm{cm}$ was found in $T_{5}$ which was statistically similar with $T_{2}, T_{3}, T_{4}$ and $T_{6}$ and the smallest plant of $76.3 \mathrm{~cm}$ was noted in control. The maximum number of effective tillers hill ${ }^{-1}$ was found in $T_{5}$ and the minimum value was observed in $T_{1}$. The largest panicle length was also found in $T_{5}$. Filled grains panicle ${ }^{-1}$ of $B R R I$ dhan50 was influenced profoundly due to application of USG alone or in combination with poultry manure. The 1000-grain weight was not influenced significantly due to different treatments. The results are in agreement with Jahan et al. (2014) who obtained similar findings from a trial with USG and PU on rice.

Table 2. Effect of PU and USG with or without organic manures on the yield components of BRRI dhan50

\begin{tabular}{|c|c|c|c|c|c|}
\hline Treatment & $\begin{array}{c}\text { Plant height } \\
(\mathrm{cm})\end{array}$ & Effective tillers hill ${ }^{-1}$ & $\begin{array}{c}\text { Panicle length } \\
(\mathrm{cm})\end{array}$ & $\begin{array}{c}\text { Filled grains } \\
\text { panicle }\end{array}$ & $\begin{array}{c}1000-\text { grain weight } \\
(\mathrm{g})\end{array}$ \\
\hline $\mathrm{T}_{1}$ & $76.3 \mathrm{~b}$ & $10.33 \mathrm{~d}$ & $18.98 \mathrm{~b}$ & $96.0 \mathrm{~b}$ & 19.25 \\
\hline $\mathrm{T}_{2}$ & $87.7 \mathrm{a}$ & $13.67 \mathrm{ab}$ & $22.69 \mathrm{a}$ & $123.0 \mathrm{a}$ & 19.80 \\
\hline $\mathrm{T}_{3}$ & $82.1 \mathrm{ab}$ & $11.67 \mathrm{c}$ & $20.74 \mathrm{ab}$ & $113.0 \mathrm{a}$ & 19.57 \\
\hline $\mathrm{T}_{4}$ & $84.7 \mathrm{a}$ & $12.33 \mathrm{c}$ & $22.08 \mathrm{a}$ & $118.7 \mathrm{a}$ & 19.75 \\
\hline $\mathrm{T}_{5}$ & $88.9 \mathrm{a}$ & $14.33 \mathrm{a}$ & $22.82 \mathrm{a}$ & $125.3 \mathrm{a}$ & 19.93 \\
\hline $\mathrm{T}_{6}$ & $86.9 \mathrm{a}$ & $12.67 \mathrm{bc}$ & $22.45 \mathrm{a}$ & $119.7 \mathrm{a}$ & 19.05 \\
\hline $\mathrm{SE}( \pm)$ & 1.91 & 0.58 & 0.61 & 4.34 & $\mathrm{NS}$ \\
\hline $\mathrm{CV} \%$ & 5.06 & 5.49 & 5.06 & 6.69 & 6.25 \\
\hline
\end{tabular}

Figures in a column having common letters do not differ significantly at $5 \%$ level of significance.

$\mathrm{CV} \%=$ Coefficient of variation, SE $( \pm)=$ Standard error of means, NS $=$ Non Significant

Grain and straw yields of BRRI dhan50: Application of PU and USG alone or in combination with poultry manure and cowdung showed a positive effect on the grain yield of BRRI dhan50 (Table 3). It was found that the grain yield ranged from $2431 \mathrm{~kg} \mathrm{ha}^{-1}$ to $4700 \mathrm{~kg} \mathrm{ha}^{-1}$. The highest grain yield was recorded in $T_{5}$ and the lowest value was recorded in $T_{1}$. The treatment $T_{3}, T_{4}$ and $T_{6}$ produced the identical grain yield. USG in association with poultry manure treated plot gave better grain yield than other treatments. This might be due to optimum release of $\mathrm{N}$ from deep placed USG for prolonged period and adequate release of $\mathrm{N}$ and other nutrients from poultry manure. Gupta et al. (1995) observed that PM and FYM produced yields of 4.1 and $3.9 \mathrm{t} \mathrm{ha}^{-1}$ of rice grain respectively. Rajput et al. (1992) reported that application of PM, FYM and cowdung with chemical fertilizers was found to produce higher grain yield than from chemical fertilizers alone. 
Table 3. Effect of PU and USG with or without organic manures on grain and straw yield of BRRI dhan50

\begin{tabular}{|c|c|c|c|c|}
\hline Treatment & Grain yield $\left(\mathrm{kg} \mathrm{ha}^{-1}\right)$ & Increase over control (\%) & Straw yield $\left(\mathrm{kg} \mathrm{ha}^{-1}\right)$ & Increase over control (\%) \\
\hline $\mathrm{T}_{1}$ & $2431 \mathrm{c}$ & - & $2930 \mathrm{c}$ & - \\
\hline $\mathrm{T}_{2}$ & $4541 \mathrm{a}$ & 86.77 & $5714 \mathrm{a}$ & 94.98 \\
\hline $\mathrm{T}_{3}$ & $3526 \mathrm{~b}$ & 45.00 & $4671 \mathrm{~b}$ & 59.38 \\
\hline $\mathrm{T}_{4}$ & $3800 \mathrm{~b}$ & 56.27 & $4790 \mathrm{~b}$ & 63.47 \\
\hline $\mathrm{T}_{5}$ & $4700 \mathrm{a}$ & 89.28 & $5888 \mathrm{a}$ & 95.92 \\
\hline $\mathrm{T}_{6}$ & $3925 \mathrm{~b}$ & 61.41 & $4918 \mathrm{~b}$ & 67.82 \\
\hline $\mathrm{SE}( \pm)$ & 332.69 & - & 429.86 & - \\
\hline $\mathrm{CV} \%$ & 6.77 & - & 7.61 & - \\
\hline
\end{tabular}

Figures in a column having common letters do not differ significantly at $5 \%$ level of significance.

$\mathrm{CV} \%=$ Coefficient of variation, SE $( \pm)=$ Standard error of means.

The straw yield of BRRI dhan50 was also influenced significantly due to the application of PU, USG, poultry manure and cowdung as shown in (Table 3). The highest straw yield of $5888 \mathrm{~kg} \mathrm{ha}^{-1}$ was obtained in $T_{5}$ and the lowest value of $2930 \mathrm{~kg} \mathrm{ha}^{-1}$ was noted in $T_{1}$. The treatments may be ranked in the order of $T_{5}>T_{2}>T_{6}>T_{4}>T_{3}>T_{1}$ in terms of straw yield as depicted in (Table 3). Regarding the percent increase of straw yield, maximum increase $(95.92 \%)$ was noted in $T_{5}$ and the minimum increase $(59.38 \%)$ was found in $T_{3}$ as demonstrated. These results support the findings of Ahmed and Rahman (1991) who reported that the application of organic matter and chemical fertilizer increased straw and grain yields of rice. Rahman et. al. (2009) reported that the application of urea-N in combination with cowdung and poultry manure increased the straw yields of rice.

\section{Nitrogen content}

Table 4 shows the effects of PU, USG, CD and PM on the nitrogen content of BRRI dhan50. The grain $\mathrm{N}$ content varied from $1.03 \%$ to $1.32 \%$. The highest $\mathrm{N}$ content of $1.32 \%$ was observed in $\mathrm{T}_{5}$ and the lowest $\mathrm{N}$ content of $1.03 \%$ was noted in $\mathrm{T}_{1}$. Application of USG in combination with poultry manure increased the $\mathrm{N}$ content in rice grain markedly in $\mathrm{T}_{5}$ which was statistically different from other treatments. In case of straw, The $\mathrm{N}$ content of BRRI dhan50 also varied significantly due to different treatments (Table 4). The $\mathrm{N}$ content in straw ranged from $0.46 \%$ in $\mathrm{T}_{1}$ to $0.75 \%$ in $\mathrm{T}_{5}$. The effect of poultry manure in combination with USG was more pronounced in increasing the $\mathrm{N}$ content both in grain and straw of BRRI dhan50 compared to other treatments. The cowdung combined with USG also increased the $\mathrm{N}$ content in both grain and straw but not like poultry manure. The results reveal that the $\mathrm{N}$ content in rice grain was higher than that of straw. Bhaskaram and Krisna, (2009) also reported a significant increase in $\mathrm{N}$ content in rice grain and straw due to manures and fertilizers application.

Table 4. Effect of PU and USG with or without organic manures on the $\mathbf{N}$ content and uptake by BRRI dhan50

\begin{tabular}{|c|c|c|c|c|c|}
\hline \multirow{2}{*}{ Treatments } & \multicolumn{2}{|c|}{$\mathrm{N}$ content (\%) } & \multicolumn{3}{|c|}{ N uptake $\left(\mathrm{kg} \mathrm{ha}^{-1}\right)$} \\
\cline { 2 - 6 } & Grain & Straw & Grain & Straw & Total \\
\hline $\mathrm{T}_{1}$ (Control) & $1.03 \mathrm{c}$ & $0.46 \mathrm{c}$ & $24.85 \mathrm{~d}$ & $13.55 \mathrm{e}$ & $38.40 \mathrm{e}$ \\
\hline $\mathrm{T}_{2}\left(78 \mathrm{~kg} \mathrm{~N} \mathrm{ha}^{-1}\right.$ from USG) & $1.30 \mathrm{ab}$ & $0.64 \mathrm{~b}$ & $59.09 \mathrm{a}$ & $36.30 \mathrm{~b}$ & $95.39 \mathrm{~b}$ \\
\hline $\mathrm{T}_{3}\left(136 \mathrm{~kg} \mathrm{~N} \mathrm{ha}^{-1}\right.$ from PU) & $1.10 \mathrm{c}$ & $0.50 \mathrm{bc}$ & $38.73 \mathrm{c}$ & $23.40 \mathrm{~d}$ & $62.13 \mathrm{~d}$ \\
\hline $\mathrm{T}_{4}\left(58 \mathrm{~kg} \mathrm{~N} \mathrm{ha}^{-1}\right.$ from USG) & $1.16 \mathrm{bc}$ & $0.54 \mathrm{bc}$ & $43.96 \mathrm{bc}$ & $25.76 \mathrm{~cd}$ & $69.72 \mathrm{c}$ \\
\hline $\mathrm{T}_{5}\left(58 \mathrm{~kg} \mathrm{~N} \mathrm{ha}^{-1}\right.$ from USG + 3 ton ha \\
PM) & $1.32 \mathrm{a}$ & $0.75 \mathrm{a}$ & $60.19 \mathrm{a}$ & $41.67 \mathrm{a}$ & $101.86 \mathrm{a}$ \\
\hline $\mathrm{T}_{6}\left(58 \mathrm{~kg} \mathrm{~N}\right.$ from USG + 5 t ha $\left.^{-1} \mathrm{CD}\right)$ & $1.17 \mathrm{abc}$ & $0.56 \mathrm{bc}$ & $45.88 \mathrm{~b}$ & $27.54 \mathrm{c}$ & $73.42 \mathrm{c}$ \\
\hline SE & 0.05 & 0.05 & 5.68 & 4.78 & 10.37 \\
\hline CV\% & 7.06 & 11.95 & 6.37 & 4.89 & 3.96 \\
\hline
\end{tabular}

Figures in a column having common letters do not differ significantly at $5 \%$ level of significance.

$\mathrm{CV} \%=$ Coefficient of variation, SE $( \pm)=$ Standard error of means. 


\section{Nitrogen uptake}

The $\mathrm{N}$ uptake both by grain and straw of BRRI dhan50 increased significantly due to application of PU, USG, poultry manure and cowdung (Table 4). The $\mathrm{N}$ uptake by grain ranged from $24.85 \mathrm{~kg} \mathrm{ha}^{-1}$ to 60.19 $\mathrm{kg} \mathrm{ha}^{-1}$ and that by straw from $13.55 \mathrm{~kg} \mathrm{ha}^{-1}$ to $41.67 \mathrm{~kg} \mathrm{ha}^{-1}$. The highest $\mathrm{N}$ uptake by grain $\left(60.19 \mathrm{~kg} \mathrm{ha}^{-}\right.$ $\left.{ }^{1}\right)$ and straw $\left(41.67 \mathrm{~kg} \mathrm{ha}^{-1}\right)$ was obtained in $\mathrm{T}_{5}$ and the lowest $\mathrm{N}$ uptake by grain $\left(24.85 \mathrm{~kg} \mathrm{ha}^{-1}\right)$ and straw (13.55 $\mathrm{kg} \mathrm{ha}^{-1}$ ) was found in $\mathrm{T}_{1}$. The total $\mathrm{N}$ uptake by rice was also influenced significantly by different treatments (Table 4). The highest total $\mathrm{N}$ uptake $\left(101.86 \mathrm{ha}^{-1}\right)$ was observed in $\mathrm{T}_{5}$ and the lowest value $\left(38.40 \mathrm{~kg} \mathrm{ha}^{-1}\right)$ was found in $T_{1}$. The treatments may be ranked in the order of $T_{5}>T_{2}>T_{6}>T_{4}>T_{3}>T_{1}$ in terms of $\mathrm{N}$ uptake. Jahan et al. (2014) reported that the $\mathrm{N}$ uptake by rice grain and straw was increased significantly with the application USG alone or in combination with poultry manure. Rahmanet al. (2009) and Akteret al. (2012) also reported similar results.

\section{Apparent N Recovery (ANR)}

The apparent $\mathrm{N}$ recovery by BRRI dhan50 has been presented in (Fig. 2A). Mean apparent recovery of $\mathrm{N}$ by rice ranged from $17.45 \%$ to $95.21 \%$. The data clearly indicate that the maximum values of apparent $\mathrm{N}$ recovery were obtained with the application of USG in combination with poultry manure. The reasons for high recovery of applied $\mathrm{N}$ could be the deep placement of USG in rice field that resulted in continuous supply of available $\mathrm{N}$ throughout the growth period of rice plant.

\section{N Use Efficiency (NUE)}

Agronomic nitrogen use efficiency (NUE) is a term used to indicate the relative balance between the amount of fertilizer $\mathrm{N}$ taken up and used by the crop versus the amount of fertilizer $\mathrm{N}$ lost. Nitrogen use efficiency represents the response of rice plant in terms of grain yield to $\mathrm{N}$ fertilizer. The highest value of NUE was obtained in $T_{5}$ and the lowest value was found in $T_{3}$. The range of NUE varied from 8.05 to 29.85 (Fig. 2B). This result indicates that application of USG in combination with poultry manure in rice field decreases the losses of $\mathrm{N}$ or the rate of $\mathrm{N}$, leading to efficient uptake and utilization of applied $\mathrm{N}$. Akter et al. (2012) and Jahan et al. (2014) also reported similar results.
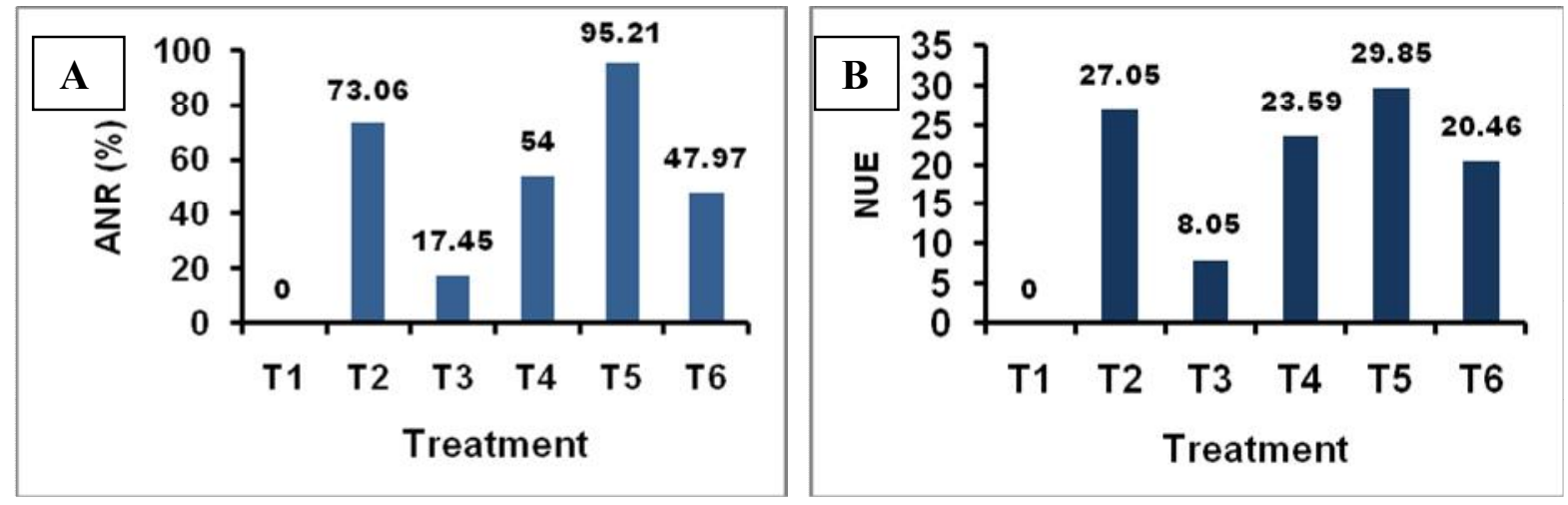

Fig. 2. Apparent $\mathrm{N}$ recovery (A) and NUE (B) of BRRI dhan50 as influenced by different treatments

\section{Conclusion}

The results of the present study indicate that treatments $T_{2}\left(78 \mathrm{~kg} \mathrm{~N} \mathrm{ha}^{-1}\right.$ from USG) and $T_{5}$ (58 kg N from USG $+3 \mathrm{t} \mathrm{ha}^{-1} \mathrm{PM}$ ) were statistically at par with in producing grain and straw yields of BRRI dhan50, but the use of $T_{5}\left(58 \mathrm{~kg} \mathrm{~N}\right.$ from USG $\left.+3 \mathrm{tha}^{-1} \mathrm{PM}\right)$ may be a better choice for rice cultivation considering the efficient use of nitrogen. However, application of $58 \mathrm{~kg} \mathrm{~N}$ from USG and $3 \mathrm{t} \mathrm{ha}^{-1} \mathrm{PM}$ may be tested in different AEZs of Bangladesh before making final inference. 


\section{References}

Ahmed, M. and Rahman, S. 1991. Influence of organic matter on the yield and mineral nutrition of modem rice and soil properties. Bangladesh Rice J. 2(1-2): 107-112.

Akter, S., Islam, M.R., Rahman, M.M. and Hoque, M.M. 2012. Influences of nitrogen supplied from inorganic and organic sources on the yield, nutrient uptake and nitrogen use efficiency of BRRI dhan29. Bangladesh J. Crop Sci. 22-23: 151-158

APHA. 1998. Standard Methods for the Examination of Water and Wastewaters. $20^{\text {th }}$ Ed. American Public Health Association, Washington, DC, USA.

Bhaskaram, U. and Krisna, D. 2009. Effect of organic farming on soil fertility, yield and quality of crops in the tropics. XVIth Int. Plant Nutri. Col. 2009, Sacramento, California. pp. 89-90.

Bhuiyan, N.I., Miah, M.A.M. and Ishaque, M. 1998. Research on USG: Findings and future research areas and recommendation. Paper presented at the National Workshop on Urea Super Granules Technology, held at BARC, Dhaka, Bangladesh, 25 June, 1998.

Black, C.A. 1965. Methods of Soil Analysis part-1 and part-II. Amer. Soc. Agron. Inc. Madison, Wiscosin, USA. p. 770

Blumenthal, J., Baltensperger, D., Cassman, K.G., Mason, S., and Pavlista, A. 2008. Importance and effect of nitrogen on crop quality and health. Agronomy \& Horticulture- Faculty Publications, Archives of Agronomy and Soil Science, Paper 200, University of Nebraska-Lincoln, NE, USA.

Bokhtiar, S.M. and Sakurai, K. 2005. Effects of organic manure and chemical fertilizer on soil fertility and productivity of plant and ratoon crops of sugarcane. Archives of Agronomy and Soil Science, 51: 325-334.

Bremner, J.M. and Mulvaney, C.S. 1982. Nitrogen-Total. In methods of soil Analysis Part 2. Edited by A.L. Page, R.H. Miller and D.R. Keeney. pp. 595-624. Amer. Soc. Agron. Inc. and Soil Sci. Soc. Amer. Inc., Madison, Wisconsin.

Dutta, S., Pal, R., Chakeraborty, A. and Chakrabarti, K. 2003. Influence of integrated plant nutrient supply system on soil quality restoration in a red and laterite soil. Archives of Agronomy and Soil Science, 49: 631-637.

FAO-UNDP. 1988. Production Yearbook, Food and Agricultural Organization of the United Nations, Rome, Italy. 57: 76-77.

Gomez, K.A. and Gomez, A.A. 1984. Statistical Procedures of Agricultural Research, $2^{\text {nd }}$ Ed., John Wiley and Sons. Inc., New York.

Gupta, R.K., Arora, B.R., Sharma, K.N. and Ahluvwalia, S.K. 2000. Influence of biogas slurry and farmyard manure application on the change in soil fertility under rice-wheat sequence. J.of Indian Soc.of Soil Science 48 (3): 500-505.

Jahan, N., Islam, M.R., Siddique, A.B., Islam, M.R., Hasan, M.M., Shamsuzzaman, S.M. and Samsuri, A.W. 2014. Effects of integrated use of prilled urea, urea super granule and poultry manure on yield of transplant aus rice and field water quality. Life Sci. J. 11(8): 101-108.

Kapoor, V., Singh, U., Patil, S.K., Magre, H., Shrivastava, L.K., Mishra, V.N., Das, R.O., Samadhiya, V.K., Sanabria, J. and Diamond, R. 2008. Rice growth, grain yield, and floodwater nutrient dynamics as affected by nutrient placement method and rate. Agron.J. 100: 526-536.

Knudsen, D., Peterson, G.A. and Pratt,P.F. 1982. Lithium, Sodium and Potassium. In methods of Soil Analysis Prt 2 edited by Page, Miller and Keenly. Amer. Soc. Agron., Inc. Publisher, USA. pp. 225-245.

Michael, P., 1965. Hydrogen-ion activity. In methods of soil analysis part 2 edited by C.A. Black. Amer. Soc. Agron., Inc. Publisher, USA pp. 914-926.

Mitchell, C.C. and Tu, S. 2006. Nutrient accumulation and movement from poultry litter.

Mohanty, S.K., Singh, U., Balasubramanian, V. and Jha, K.P. 1999. Nitrogen deep placement technologies for productivity, profitibility and environmental quality of rainfed low land rice systems. Resource management in rice systems. Nutrient Cycling in Agroecosystems. 53(1): 43-57.

Olsen, S.R., Cole, C.U., Watanable, F.S. and Deun, L.A. 1954. Estiamtion of available P in soil extraction with sodium bicarbonate. U.S. Agril. Cir. pp: 929.

Rahman, M.S., Islam, M.R., Rahman, M.M. and Hossain, M.I. 2009. Effect of cowdung, Poultry manure and Urea-N on the yield and nutrient uptake of BRRI Dhan-29. J. Bangladesh Res. Pub. 2(2): 552-558.

Rajput, A.L., Warsi, A.S. and Verma, L.P. 1992: Residual effect of different organic materials and nitrogen levels on wheat grown after rice (Oryza sativa L.). Indian J. of Agron. 37(4): 783-784.

Rochette, P., Angers, D.A., Chantigny, M.H., MacDonald, J.D., Bissonnette, N. and Bertrand, N. 2009. Ammonia volatilization following surface application of urea to tilled and no-till soils: A laboratory comparison. Soil and Tillage Research, 103(2): 310-315.

Walkley and Black, C.V. 1934. An examination of the Degtjereff method for determining soil organic matter and a proposed modification for the chromic acid titration method. Soil Sci. 37: 29-38.

Wang, Z.H., Liu, X.J., Ju, X.T., Zhang F.S., and Malhi, S.S. 2004. Ammonia volatilization loss from surface-broadcast urea: comparison of vented- and closed-chamber methods and loss in winter wheat-summer maize rotation in north China plain. Communications in Soil Science and Plant Analysis, 35: 2917-2939.

Williams, C.H. and Stenbergs, A. 1959. Soil sulphur fractions as chemical indices of available sulphur in some Australian soils: Aust. J. Agric. Res. 10: 340-352. 